УДК 34.01

\title{
ПРАВОВОЕ ЗАКРЕПЛЕНИЕ ПОРЯДКА ОРГАНИЗАЦИИ МЕДИЦИНСКОЙ ПОМОЩИ НОВОРОЖДЕННЫМ И МАЛОЛЕТНИМ ДЕТЯМ НА ПРИМЕРЕ ЗАКОНОВ ВТОРОЙ ПОЛОВИНЫ ХVIII В. И СОВРЕМЕННОЕ НОРМАТИВНОЕ РЕГУЛИРОВАНИЕ
}

\author{
Печникова Ольга Глебовна \\ докт.юр.н., доцент \\ профессор кафедры теории \\ и истории государства и права
} ФБОУ ВО РГУ нефти и газа (национальный исследовательский университет) им. И.М. Губкина

\begin{abstract}
Аннотация: В статье автор анализирует правовые и иные документы закрепляющие порядок организации медицинской помощи новорожденным и малолетним детям во второй половине XVIII в., глубоко осмысливая рассматриваемые материалы. Аргументирует выводы о том, что ранее осуществлявшееся несистемное нормативное регулирование данного раздела государственных задач, в указанный период начинает приобретать все большее значение и внимание со стороны законодателя. Отмечает схожесть вектора направленности государственной заботы о будущем поколении в документах, в дальнейшем, определяющих законотворчество XXI века, в качестве приоритетных и перспективных целей Российской Федерации.

Ключевые слова: Личные права граждан РФ; история нормативного регулирования порядка организации медицинской помощи новорожденным и малолетним детям; история медицинского права; медицинские законы 17 века; правовое закрепление правил организации медицинской помощи новорожденным и малолетним детям.
\end{abstract}

\section{LEGAL CONSOLIDATION OF THE PROCEDURE FOR ORGANIZING MEDICAL CARE FOR NEWBORNS AND YOUNG CHILDREN ON THE EXAMPLE OF LAWS SECOND HALF OF THE 18TH CENTURY AND MODERN REGULATIONS}




\section{Pechnikova O.G.}

Abstract: In the article, the author analyzes legal and other documents establishing the procedure for organizing medical care for newborns and young children in the second half of the 18th century, deeply comprehending the materials under consideration. Arguments the conclusions that the previously carried out nonsystemic normative regulation of this section of state tasks, during this period, begins to acquire more and more importance and attention from the legislator. Notes the similarity of the vector of direction of state care for the future generation in the documents, in the future, defining the lawmaking of the XXI century, as the priority and promising goals of the Russian Federation.

Key words: Personal rights of citizens of the Russian Federation; the history of normative regulation of the procedure for organizing medical care for newborns and young children; history of medical law; medical laws of the 17th century; legal consolidation of the rules for organizing medical care for newborns and young children.

Нормативное регулирование порядка организации медицинской помощи новорожденным и малолетним детям до второй половины XVIII в., по нашему мнению, не носило системного характера. Среди первых государственных законов, обращенных к данной государственной проблеме, можно назвать Сенатский указ от 2 июля 1759 г. «Об отпускании для бедных родильниц и новорожденных младенцев лекарства, по рецептам докторов и акушеров, из казенных аптек безденежно» [1]: в аптеках предусматривался «особливый счет», а сведения о расходах предоставлялись ежегодно в Медицинскую канцелярию; предусматривалось также применение санкций в виде денежных штрафов с виновных при незаконном использовании средств оказания медицинской помощи, тем, кому она не предназначалась.

Согласно Манифесту, с приложением, утвержденного Екатериной II проекта генерал-поручика Бецкого от 1 сентября 1763 г. «Об учреждении в Москве Воспитательного дома, с особливым гошпиталем для неимущих родильниц» [2], - предполагалось оказывать «призрение бедным и попечение о умножении полезных обществу жителей». Большое внимание в документе уделялось необходимости воспитания нравственности, трудолюбия, 


\section{НАУКА, ОБЩЕСТВО, КУЛЬТУРА: ПРОБЛЕМЫ И ПЕРСПЕКТИВЫ ВЗАИМОДЕЙСТВИЯ В СОВРЕМЕННОМ МИРЕ}

добродетельности, важности «сего богоугодного мероприятия, что есть действие беспредельнаго милосердия ея императорскаго величества».

После выхода Манифеста, с приложением, Высочайше утвержденного проекта генерал-поручика Бецкого от 1 сентября 1763 г. «Об учреждении в Москве Воспитательного дома, с особливым гошпиталем для неимущих родильниц», 11 августа 1767 г. был утвержден «Генеральный план Московского Воспитательного для приносных младенцев дома. Часть вторая» (данный закон в период правления Екатерины II также имел продолжение в виде Сенатского указа, с приложением объявления Опекунского совета Воспитательного дома от 21 декабря 1772 г. «О воспитании оставленных родителями младенцев до пяти лет; о приносе оных в Воспитательный дом и о платеже за воспитание», где, в качестве дополнения, публиковался поименный состав Опекунского совета [3]).

Экономические проблемы, конечно же, оказывали существенное влияние на невозможность сокращения сроков, поэтому мы видим медленное осуществление планов в период империи. Но, тем ни менее, понимание актуальности увеличения числа населения для реализации тех же самых проблем, являлась уже глубоко осмысленной на высочайшем уровне.

Итак, «Генеральный план Московского Воспитательного для приносных младенцев дома. Часть вторая» вводил определенные требования к застройке помещения и размещению больных: «Надобно только ... чтоб уставы и узаконения во всем наиточнейше исполняемы были». Имелись рекомендации по соблюдению карантина в отношении больных детей, чистоте, физических упражнениях, сне, играх и прочем.

20 ноября 1772 г. вышло «Высочайше утвержденное Генерального плана Императорского Воспитательного дома исполнительное учреждение вдовьей, ссудной и сохранной казны в пользу всего общества» [4]. Оно, за месяц, претерпело ряд текстовых доработок, но сохранило прежний смысл и 21 декабря 1772 г. завершилось изданием Сенатского указа с приложением объявления опекунского совета Воспитательного дома «О воспитании оставленных родителями младенцев до пяти лет; о приносе оных в Воспитательный дом и о платеже за воспитание» [5]. Документы представляют научный интерес в части порядка финансирования и денежных выплат: жалованье кормилицам и воспитателям увеличивалось до «5 рублей на человека» и выплачивалось «из доходов Коллегии экономии», по «учиненной о том ведомости Правительствующему сенату» [6]. 


\section{НАУКА, ОБЩЕСТВО, КУЛЬТУРА: ПРОБЛЕМЫ И ПЕРСПЕКТИВЫ ВЗАИМОДЕЙСТВИЯ В СОВРЕМЕННОМ МИРЕ}

Екатерина II принимала личное участие в нормотворчестве, подтверждение данного утверждения мы может обнаружить в следующем нормативном документе. Так, 16 ноября 1766 г., «в Московския присутственные места, також в губернии, провинции и города, в Московские Правительствующаго сената департаменты и в Святейший синод при ведениях» было разослано, имевшее пометки императрицы, «Краткое наставление, выбранное из лучших авторов с некоторыми физическими примечаниями о воспитании детей от рождения до юношества» [7], содержащее рекомендации о вскармливании и одежде младенцев, обращении с детьми и профилактике заболеваемости.

Отметим также параграфы-инструкции: «О чистоте», «О банях», «О упражнениях», они сохранили свою актуальность и по сей день. В Наказе выделялись параграфы: - «О лекарствах», - содержащие распоряжение «без необходимой нужды отнюдь детям крови не пускать, ни лекарств для предосторожности не давать ..., всего лучше заставлять его играть на вольном воздухе», а также - «О прививании оспы», в котором, в частности, говорится: «От 5, 6 или еще моложе, до 8 и 10 лет, надлежит детям прививать оспу».

Таким образом, кроме лечения, воспитания и содержания, государство стало планировать осуществление профилактических мер с целью сохранения здоровья данной категории лиц. Тот же вектор направленности государственно заботы о будущем поколении присутствует в документах, определяющих законотворчество XXI века.

Современный порядок организации медицинской помощи новорожденным и малолетним детям закреплен конституцией, федеральными законами РФ и ее субъектов, указами Президента, рядом подзаконных актов и ведомственными распоряжениями, входящими в нормативно определенное правовое поле. Среди всего, нами перечисленного, особое место занимает Федеральный закон «Об основах охраны здоровья граждан в Российской Федерации» № 323-Ф3 от 21.11.2011 (ред. от 30. 04. 2021), где кроме предмета правового регулирования и гарантий прав граждан, в гл. 2 ст. 7 содержится определение приоритета охраны здоровья детей, а ст. в 12 - приоритета мер профилактической направленности.

Дальнейшая разработка данных разделов, несомненно, отражает глубокое понимание на высочайшем уровне перспектив развития общества, государства 
и ее граждан, в целом: здоровое поколение наиболее эффективно может реализовать глобальные и личные планы в демократической стране.

\section{Список литературы}

1. Полное собрание законов Российской Империи (далее - ПСЗ РИ). Собр. 1. Т. ХV. СПб., 1830. № 10972.

2. ПСЗ РИ. Собр. 1. Т. ХVI. СПб., 1830. № 11908.

3. ПСЗ РИ. Собр. 1. Т. ХVII. СПб., 1830. № 12785; ПСЗ РИ. Т. ХІХ. СПб., 1830. № 13930.

4. ПСЗ РИ. Собр. 1. Т. ХІХ. СПб., 1830. № 13909.

5. ПСЗ РИ. Собр. 1. Т. ХІХ. СПб., 1830. № 13930.

6. ПСЗ РИ. Собр. 1. Т. ХVІ. СПб., 1830. № 11908; ПСЗ РИ. Собр. 1. Т. ХІХ .СПб., 1830. № 13909; ПСЗ РИ. Собр. 1. Т. ХІХ. СПб., 1830. № 13930.

7. ПСЗ РИ. Собр. 1. Т. ХVII. СПб., 1830. № 12785. 